\title{
Efficient Diagnosis of Ratoon Stunting Disease of Sugarcane by Quantitative PCR on Pooled Leaf Sheath Biopsies
}

Anthony J. Young, Centre for Crop Health, Faculty of Health, Engineering and Sciences, University of Southern Queensland, QLD, 4350, Australia; Asuka Kawamata, Southern Cross Plant Science, Southern Cross University, NSW, 2480, Australia; Mark A. Ensbey, Sunshine Sugar, Harwood Sugar Mill, Harwood Island, NSW, 2465, Australia; and Eleanore Lambley and Catherine J. Nock, Southern Cross Plant Science, Southern Cross University

\begin{abstract}
Young, A. J., Kawamata, A., Ensbey, M. A., Lambley, E., and Nock, C. J. 2016. Efficient diagnosis of ratoon stunting disease of sugarcane by quantitative PCR on pooled leaf sheath biopsies. Plant Dis. 100:2492-2498.

Ratoon stunting disease (RSD), caused by the bacterium Leifsonia xyli subsp. $x y l i$, is arguably one of the most devastating diseases of sugarcane. Four diagnostic techniques were compared for 100 fields of sugarcane (Saccharum interspecific hybrids) of unknown infection status. These were quantitative polymerase chain reaction on pooled leaf sheath biopsies (LSB-qPCR), conventional PCR on the same templates (LSB-PCR), evaporative-binding enzyme immunoassay (EB-EIA) coupled with phase contrast microscopy (PCM) on expressed xylem sap from the same fields, and conventional PCR on the same xylem sap samples. LSB-qPCR and LSB-PCR detected the causal agent in 27 and 18 fields, respectively,

whereas, from samples of expressed xylem sap from the same fields, conventional PCR identified 12 infections and EB-EIA/PCM detected L. xyli subsp. $x y l i$ in 3 fields. The sensitivities of qPCR and PCR were approximately $10^{3}$ and $10^{4} \mathrm{CFU} \mathrm{ml}{ }^{-1}$, respectively, determined from plate counts of a dilution series. Tests were conducted on a further 139 LSB samples from across the Australian industry, with qPCR and PCR diagnosing RSD in 31 and 25 fields, respectively. Using qPCR and PCR on LSB samples, RSD was diagnosed in a range of cultivars throughout the year, and qPCR and PCR could detect $L$. xyli subsp. xyli in sugarcane ranging from 3 months to greater than 1 year old.
\end{abstract}

Ratoon stunting disease (RSD), caused by the bacterium Leifsonia xyli subsp. xyli (Davis et al. 1984; Evtushenko et al. 2000), is the most insidious and economically significant disease of sugarcane (Saccharum interspecific hybrids) (Gillaspie and Teakle 1989; Young and Brumbley 2004). The bacteria extend systemically through the xylem vessels, interfering with water and nutrient transport, thereby reducing growth (Bailey 1977; Teakle et al. 1978). Because RSD is vegetatively transmitted by infected propagation material and further spread during mechanical harvesting, a key management tool is diagnosis of the disease in fields before they are used as plant sources to establish new crops. However, diagnosis of RSD is difficult owing to the absence of specific external symptoms and the ambiguous nature of the internal symptoms (Hughes and Steindl 1956). This is further complicated by the possibility that, within an infected crop, not all stools may be infected.

Shortly after its discovery in 1945, RSD diagnosis was performed by mechanically inoculating the highly susceptible 'Q28' sugarcane with juice from test plants, then comparing the growth and internal symptoms with non-inoculated controls (Hughes and Steindl 1956). When the bacterial causal agent was discovered, diagnosis was based on microscopic examination of expressed xylem sap (Teakle et al. 1973). Axenic isolation of the pathogen (Davis et al. 1980) facilitated the development of multiple immunological platforms that have been widely adopted throughout the world's sugarcane industries. In Australia, the evaporative-binding enzyme immunoassay (EB-EIA) on expressed xylem sap has been the standard diagnostic since 1994 (Croft et al. 1994, 2004). Since then, a suite of highly sensitive molecular methods have been developed for detection of $L$. xyli subsp. xyli, including conventional polymerase chain reaction (PCR) (Fegan et al. 1998; Pan et al. 1998; Taylor et al. 2003), nested PCR (Farahani et al. 2015), quantitative PCR (qPCR) (Carvalho et al. 2016; Gao et al.

Corresponding author: A. J. Young; E-mail: anthony.young2@usq.edu.au

Accepted for publication 12 August 2016.

http://dx.doi.org/10.1094/PDIS-06-16-0848-RE

(C) 2016 The American Phytopathological Society
2008; Grisham et al. 2007; Pelosi et al. 2013) and loop-mediated isothermal amplification (LAMP) (Ghai et al. 2014; Liu et al. 2013). However, these do not appear to have been widely deployed for commercial screening.

The diagnostic efficiency for RSD hinges not only on the sensitivity of the test but also on the sampling strategy employed. For EBEIA, sample collection routinely involves collecting 16 stalks per field, scrubbing them clean of extraneous matter, cutting them into single node lengths, and then pumping the xylem sap, typically pooling the sap from 4 stalks into each of four tubes. Any tube that registers an EB-EIA absorbance of 0.05 or more is subject to retesting with EB-EIA but infection is only confirmed after observing $L$. xyli subsp. xyli cells using phase contrast microscopy (PCM) in at least one sample. Owing to transpiration, collection of xylem sap is generally restricted to the morning, which imposes limitations on the duration and extent of surveys. It is difficult to extract xylem sap from small stalks using this method; therefore, Australian industry guidelines recommend targeting the largest stalk in the smallest stools to improve the chance of detection (Croft and Cox 2013). Although the possibility of under-diagnosis using this platform has previously been raised (Young et al. 2012), increasing the confidence level by sampling significantly more stalks is time and cost prohibitive.

Given that $L$. xyli subsp. xyli spreads systemically through the plant (Bailey 1977), leaf tissue assays may improve diagnostic efficiency by increasing field coverage (Gillaspie 1987; Grisham et al. 2007; Young 2003). Most DNA extraction methods are costly and time consuming, and molecular diagnostics on DNA extractions from pooled tissue samples may be affected by saturation of target DNA with plant DNA, particularly when bacterial titers are low. However, it has been demonstrated that $L$. xyli subsp. xyli cells can be used directly as templates for PCR (Brumbley et al. 2006; Young et al. 2006); therefore, it was considered possible that RSD diagnosis could be achieved using templates derived from pooled leaf sheath biopsies (LSB) without DNA extraction steps (LSB-PCR) (Young et al. 2014). The initial report showed that LSB-PCR detected RSD in almost twice as many fields as EB-EIA/PCM.

The current work aimed to determine whether qPCR could effectively detect $L$. $x y l i$ subsp. xyli in LSB templates and provide a simple, cost-effective closed-tube diagnostic for RSD. Another objective 
was to compare the results of LSB-qPCR and LSB-PCR with EBEIA/PCM on xylem sap collected from the same fields, as well as PCR on duplicate xylem sap samples, to determine the relative sensitivity of the different techniques. Furthermore, we aimed to determine whether LSB-qPCR and LSB-PCR could diagnose RSD in different regions and times of the year and in young crops.

\section{Materials and Methods}

Sample collection. The oldest and southernmost sugarcane production area in Australia is centered around Harwood, New South Wales (NSW), a rainfed industry of approximately 10,000 ha that largely harvests 2-year old, or standover, cane. As part of ongoing RSD management, during the annual plant source inspection between June and August 2014, 100 fields of different sugarcane cultivars of unknown infection status were sampled for analysis using four diagnostic platforms. These included conventional PCR on concentrated suspensions from 50 pooled LSB (LSB-PCR) (Young et al. 2014), and a qPCR technique (Grisham et al. 2007) on the same LSB samples (LSB-qPCR). The standard Australian protocol of EB-EIA and PCM was conducted on four xylem sap samples taken from the same fields, each containing sap samples from 4 stalks (16 stalks in total). Conventional PCR (Pan et al. 1998) on duplicate aliquots of the same xylem sap samples was also conducted.

Xylem sap samples were collected as per industry guidelines, whereby 16 stalks were cut at the base using sterilized secateurs and scrubbed free of extraneous matter, and the xylem sap expressed under positive pressure from basal nodal and internodal sections. Following expression of approximately $2 \mathrm{ml}$ of xylem sap for EB-EIA (from four stalks per tube), and prior to the addition of a single drop of chlorhexidine preservative as per the EB-EIA protocol, a 25- $\mu$ l aliquot was transferred into sterile 100- $\mu$ l tubes for PCR analysis. Xylem sap samples were sent for EB-EIA analysis to the Sugar Research Australia (SRA) RSD laboratory in Brisbane, Queensland, Australia, while the subsample aliquots were analyzed by conventional PCR at the Southern Cross Plant Sciences laboratory, Southern Cross University, Lismore, NSW, Australia. As is standard practice, any sample that recorded an absorbance of 0.05 or greater was subjected to retesting via EB-EIA, while final confirmation of infection was conducted by PCM.

LSB samples were collected using a purpose-built, 11-mm-diameter cork borer device in accordance with optimized procedures described by Young et al. (2014). For each field, 50 LSB were collected by targeting the lowermost green leaf sheath (that is, the oldest leaf sheath before senescence) of a convenient stalk in the first stool of 50 rows. Where there were fewer than 50 rows, additional stools were sampled from elsewhere in the field until 50 LSB from the target cultivar were collected. These were transferred into the corner of a small zip-lock plastic bag, overlaid with approximately $5 \mathrm{ml}$ of distilled water (sufficient just to cover them), incubated at $4^{\circ} \mathrm{C}$ overnight, then frozen until required for processing, which occurred between 1 day and 2 weeks after collection. Samples were processed by transferring $1.6 \mathrm{ml}$ of the aqueous suspension into a $2-\mathrm{ml}$ plastic centrifuge tube, allowing any debris to settle for approximately $5 \mathrm{~min}$, then transferring $1.5 \mathrm{ml}$ of the upper part of the suspension into a fresh $1.5-\mathrm{ml}$ centrifuge. This was centrifuged for $15 \mathrm{~min}$ at $13,000 \mathrm{rpm}$, the supernatant was decanted, then the residual water was removed by pipetting after pulse centrifugation. The resulting material was resuspended in $50 \mu \mathrm{l}$ of water by running it down the side of the centrifuge tube, where any bacterial cells would be deposited, and pipetting several times.

To determine the efficacy of the LSB platform in other areas and times of the year, samples were solicited from the 14 sugarcane-growing areas in Queensland, Australia. Furthermore, to determine whether the technique worked at different times of the year, two fields (fields 160 and 168; Table1) which were determined to be infected through the earlier part of this research were resampled monthly from February through April 2015. Field 160 was also sampled in January 2016, when the crop was 15-month-old standover. In addition, one field (161) that was deemed positive by EB-EIA/PCM but negative for all other methods was sampled monthly between February and April inclusive. All samples were processed as above, and screened using the qPCR and conventional PCR protocols described below.
Conventional PCR conditions and gel electrophoresis. PCR was conducted on LSB-derived templates, expressed xylem sap, and a dilution series of cultured $L$. xyli subsp. xyli cells using Cxx1 and Cxx2 primers (Pan et al. 1998). Reactions were conducted in $25-\mu$ l volumes, using $12.5 \mu$ l of $2.5 \times$ Amplitaq Gold 360 mastermix premix (Life Technologies), $1.25 \mu \mathrm{l}$ of $4 \mu \mathrm{M}$ each primer, $9 \mu \mathrm{l}$ of water, and $1 \mu \mathrm{l}$ of template. Thermal cycling was conducted using a Corbett Palm Pilot Cycler CG1-96. The following thermocycle profile was used for PCR: $96^{\circ} \mathrm{C}$ for $5 \mathrm{~min} ; 40$ cycles of $95^{\circ} \mathrm{C}$ for $30 \mathrm{~s}$, $60^{\circ} \mathrm{C}$ for $15 \mathrm{~s}$, and $72^{\circ} \mathrm{C}$ for $30 \mathrm{~s}$; then a final extension of $72^{\circ} \mathrm{C}$ for $5 \mathrm{~min}$. Products were electrophoresed on $1.5 \%$ agarose gels cast and run in $0.5 \times$ Tris-borate EDTA buffer. Bands were visualized using Gel Red stain and the Bio-Rad XR+ gel documentation system.

qPCR conditions. qPCR was conducted on LSB-derived templates and bacterial suspensions using $L$. xyli subsp. xyli-specific primers Lxx202F and Lxx331R designed to amplify a 130-bp section of the intergenic spacer (IGS) region between the $16 \mathrm{~S}$ and $23 \mathrm{~S}$ ribosomal RNA (rRNA) genes (Grisham et al. 2007). However, a 2-bp mismatch was detected between the forward primer Lxx202F and the L. xyli subsp. xyli genome sequence (GenBank accession NC_006087); therefore, a new primer, Lxx202FB (5'-CGAACTTAGTACGCCT $\underline{\text { GC }}$ TTG-3'), was synthesized (corrected mismatch highlighted). The primers Lxx202FB and Lxx331R (5'-GGATTCGGTTCTCATCTC-3') were used in subsequent qPCR. Reactions were performed for three technical replicates of each sample using a Rotogene $\mathrm{Q}$ instrument (Qiagen). Reaction mixtures contained $1 \mu$ l of LSB extract template, $12.5 \mu \mathrm{l}$ of SYBR Green PCR Master Mix (Qiagen), $1.25 \mu \mathrm{l}$ of $20 \mu \mathrm{M}$ forward Lxx202FB and reverse Lxx331R primers, and purified water to a final volume of $24 \mu \mathrm{l}$. No-template controls contained $1 \mu l$ of purified water in place of LSB extract. Positive controls contained $1 \mu$ l of a 1:10 dilution of an aqueous suspension of cultured L. xyli subsp. xyli. To test for PCR inhibition, each LSB extract was separately subjected to qPCR using control primers (ADF for, $5^{\prime}-\mathrm{CT}$

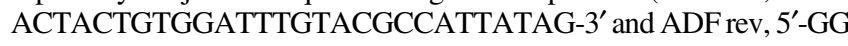
ACCTTTTTTACACAGCAAGAAAC-3') (N. Thompson, personal communication) designed for the sugarcane actin depolymerization factor gene. Thermal cycling conditions consisted of $5 \mathrm{~min}$ at $95^{\circ} \mathrm{C}$ followed by 40 cycles of denaturation at $95^{\circ} \mathrm{C}$ for $10 \mathrm{~s}$, annealing at $60^{\circ} \mathrm{C}$ for $30 \mathrm{~s}$, and extension for $10 \mathrm{~s}$ at $72^{\circ} \mathrm{C}$. To facilitate scoring of results based on melt-curve analysis of PCR amplicons, a melt step followed qPCR amplification, consisting of linear temperature ramping from 60 to $95^{\circ} \mathrm{C}$, rising by $1{ }^{\circ} \mathrm{C}$ per step, with $90 \mathrm{~s}$ of premelt conditioning on the first step and $5 \mathrm{~s}$ for subsequent steps. Samples with an L. xyli subsp. xyli specific melt peak in comparison with the positive controls for two or three of the technical replicates were deemed positive.

Assay sensitivity. L. xyli subsp. xyli isolate DNPRC118 (Young et al. 2006) was grown on modified sugar cane (M-SC) medium (Brumbley et al. 2002; Davis et al. 1980) that was further modified by the addition of methionine at $0.5 \mathrm{~g} \mathrm{liter}^{-1}$ as part of the filtered component (Monteiro-Vitorello et al. 2004). After 10 days, sufficient bacterial growth was present to transfer a small amount of confluent bacterial growth into $300 \mu \mathrm{l}$ of sterile water in a $1.5-\mathrm{ml}$ centrifuge tube using a flame-sterilized loop. This was thoroughly mixed before being used to seed a series of eight 1:10 dilutions by successively adding $100 \mu \mathrm{l}$ of suspension to $900 \mu \mathrm{l}$ of water, mixing, and then repeating the process. Once the dilution series was prepared, $100 \mu \mathrm{l}$ of each suspension was spread onto duplicate modified M-SC plates and spread using a flame-sterilized glass spreader. All plates were sealed and incubated at $28^{\circ} \mathrm{C}$ for approximately 3 weeks, and colony counts were then conducted to calculate the $L$. xyli subsp. xyli titers in the dilution series. The remaining suspensions were used as template for qPCR and conventional PCR.

DNA sequencing and analysis. A Qiagen PCR clean-up column was used to purify the remaining $20 \mu \mathrm{l}$ of product for each sample that was positive by conventional PCR. DNA sequences were obtained by direct Sanger sequencing using the respective forward and reverse amplification primers and an ABI PRISM 3730 Genetic Analyzer (Applied Biosystems). Sequences were aligned using MUSCLE in MEGA6 (Tamura et al. 2013), and compared with existing sequence data using 
the BLASTn algorithm of the National Center for Biotechnology Information website.

\section{Results}

Sample collection. One hundred fields comprising 14 cultivars of unknown RSD status were screened using EB-EIA/PCM and conventional PCR on duplicate samples of expressed xylem sap from 16 stalks per field, as well as qPCR and conventional PCR on templates derived from 50 pooled LSB (LSB-qPCR and LSB-PCR) from the same fields. The average age of each field was 9 months. In total, 33 fields comprising 11 cultivars were diagnosed positive for $L$. xyli subsp. xyli using one or a combination of the diagnostic platforms tested (Table 1).

Field diagnostic comparison. L. xyli subsp. xyli was detected by LSB-qPCR in 27 fields, LSB-PCR in 18 fields, and PCR on expressed xylem sap in 12 fields, while EB-EIA/PCM returned 6 positive fields, 3 of which were negative for the other methods, including PCR on duplicate xylem sap samples. To test whether the PCR-negative but EB-EIA/PCM-positive expressed xylem sap contained related bacteria that may have triggered a response to the polyclonal antibodies employed in EB-EIA, a separate PCR was conducted using Leifsonia-generic primers (Young 2003). Amplicons were obtained for all three samples, and sequence data from two of the fields confirmed the presence of strains related to but distinct from L. xyli subsp. xyli (Table 1). However, the third sequence could not be obtained owing to a consistently weak amplified fragment.

All of the LSB samples that were positive by conventional PCR were also positive by qPCR, while nine of these fields were also positive by conventional PCR on expressed xylem sap. Two fields were positive via all four methods. Three PCR and sequence-confirmed positive xylem sap samples came from fields that were negative for both LSB protocols. All sequences obtained with the Cxx1 and Cxx2 primers shared $100 \%$ identity with published $L$. xyli subsp. xyli 16S23S rRNA IGS sequence (GenBank accession AE016822) (MonteiroVitorello et al. 2004). Sequences from this study have been deposited in GenBank, with accessions provided in Table 1.

In total, 139 LSB samples comprising 16 cultivars were received from 9 of the 14 Queensland sugarcane production areas between April and November 2015. LSB-qPCR detected L. xyli subsp. xyli in 31 fields, 25 of which were also positive using conventional

Table 1. Comparison of diagnostic techniques for detecting Leifsonia xyli subsp. xyli infection of sugarcane fields ${ }^{\mathrm{a}}$

\begin{tabular}{|c|c|c|c|c|c|c|c|c|c|}
\hline Field & Cultivar & Crop class $^{b}$ & LSB-qPCR ${ }^{\mathbf{c}}$ & Mean Ct value ${ }^{d}$ & LSB-PCR $^{\mathrm{e}}$ & Xylem PCR & EB-EIA/PCMg & Sequence $^{h}$ & GenBank $^{i}$ \\
\hline 004 & Q235 & $\mathrm{RP}$ & +++ & 23.61 & + & + & + & $L x x$ & KU246030 \\
\hline 018 & $\mathrm{Q} 232$ & $1 \mathrm{R}$ & +++ & 25.84 & + & + & + & $L x x$ & KU246032 \\
\hline 204 & $75 C-326$ & $\mathrm{RP}$ & +++ & 22.12 & + & + & - & $L x x$ & KU246015 \\
\hline 013 & Q234 & $\mathrm{RP}$ & +++ & 23.18 & + & + & - & $L x x$ & KU246029 \\
\hline 168 & Q232 & $1 \mathrm{R}$ & +++ & 24.97 & + & + & - & $L x x$ & KU246028 \\
\hline 035 & Arris & $1 \mathrm{RR}$ & +++ & 25.39 & + & + & - & $L x x$ & KU246017 \\
\hline 160 & BN83-3120 & $1 \mathrm{R}$ & +++ & 27.27 & + & + & - & $L x x$ & KU246026 \\
\hline 015 & BN83-3120 & $\mathrm{RP}$ & +++ & 27.49 & + & + & - & $L x x$ & KU246024 \\
\hline 039 & Arris & $\mathrm{RP}$ & ++- & 28.46 & + & + & - & $L x x$ & KU246016 \\
\hline 034 & Q232 & $1 \mathrm{R}$ & +++ & 23.95 & + & - & - & $L x x$ & KU246027 \\
\hline 014 & BN83-3120 & $\mathrm{RP}$ & ++- & 24.05 & + & - & - & $L x x$ & KU246022 \\
\hline 020 & BN83-3120 & $\mathrm{RP}$ & +++ & 25.78 & + & - & - & $L x x$ & KU246025 \\
\hline 163 & Q232 & $\mathrm{P}$ & +++ & 25.79 & + & - & - & $L x x$ & KU246031 \\
\hline 023 & BN83-3120 & $\mathrm{RP}$ & +++ & 26.01 & + & - & - & $L x x$ & KU246021 \\
\hline 027 & BN83-3120 & $\mathrm{RP}$ & ++- & 26.17 & + & - & - & $L x x$ & KU246019 \\
\hline 025 & BN83-3120 & $3 R R$ & ++- & 27.55 & + & - & - & $L x x$ & KU246020 \\
\hline 016 & BN83-3120 & $\mathrm{RP}$ & ++- & 28.95 & + & - & - & $L x x$ & KU246023 \\
\hline 005 & BN83-3120 & $\mathrm{RP}$ & ++- & 29.02 & + & - & - & $L x x$ & KU246018 \\
\hline 064 & Q208 & $\mathrm{P}$ & ++- & 25.28 & - & - & - & $\mathrm{n} / \mathrm{a}$ & $\mathrm{n} / \mathrm{a}$ \\
\hline 101 & BN83-3120 & $2 \mathrm{R}$ & +++ & 26.10 & - & - & - & $\mathrm{n} / \mathrm{a}$ & $\mathrm{n} / \mathrm{a}$ \\
\hline 104 & Q242 & $\mathrm{RP}$ & +++ & 26.55 & - & - & - & $\mathrm{n} / \mathrm{a}$ & $\mathrm{n} / \mathrm{a}$ \\
\hline 152 & Q208 & $\mathrm{P}$ & +++ & 27.34 & - & - & - & $\mathrm{n} / \mathrm{a}$ & $\mathrm{n} / \mathrm{a}$ \\
\hline 154 & Q242 & $\mathrm{P}$ & +++ & 27.99 & - & - & - & $\mathrm{n} / \mathrm{a}$ & $\mathrm{n} / \mathrm{a}$ \\
\hline 019 & BN83-3120 & $1 \mathrm{RR}$ & ++- & 28.15 & - & - & - & $\mathrm{n} / \mathrm{a}$ & $\mathrm{n} / \mathrm{a}$ \\
\hline 006 & BN83-3120 & $1 \mathrm{RR}$ & +++ & 28.55 & - & - & - & $\mathrm{n} / \mathrm{a}$ & $\mathrm{n} / \mathrm{a}$ \\
\hline 157 & Arris & $\mathrm{P}$ & ++- & 29.34 & - & - & - & $\mathrm{n} / \mathrm{a}$ & $\mathrm{n} / \mathrm{a}$ \\
\hline 028 & SP79-2313 & $\mathrm{RP}$ & ++- & 29.45 & - & - & - & $\mathrm{n} / \mathrm{a}$ & $\mathrm{n} / \mathrm{a}$ \\
\hline 017 & BN83-3120 & $\mathrm{RP}$ & --- & $\mathrm{n} / \mathrm{a}$ & - & + & - & $L x x$ & KU246033 \\
\hline 030 & Q183 & $\mathrm{RP}$ & --- & $\mathrm{n} / \mathrm{a}$ & - & + & - & $L x x$ & KU246034 \\
\hline 022 & Q232 & $\mathrm{RP}$ & --- & $\mathrm{n} / \mathrm{a}$ & - & + & + & $L x x$ & KU297984 \\
\hline 161 & Q208 & $\mathrm{P}$ & +-- & $\mathrm{n} / \mathrm{a}$ & - & - & + & $\operatorname{non} L x x$ & KU297986 \\
\hline 010 & Q243 & $1 \mathrm{RR}$ & --- & $\mathrm{n} / \mathrm{a}$ & - & - & + & $\operatorname{non} L x x$ & KU297985 \\
\hline 158 & Q183 & $1 \mathrm{R}$ & +-- & $\mathrm{n} / \mathrm{a}$ & - & - & + & $\operatorname{non} L x x$ & $*$ \\
\hline
\end{tabular}

a Note that, out of 100 fields tested, data are shown only for the 33 that were deemed positive for one or more diagnostic test.

${ }^{\mathrm{b}}$ Crop class key: $\mathrm{P}=$ plant cane into fallow, $\mathrm{RP}=$ replant, where a new crop was planted into a field that had a previous crop plowed out that season, $1 \mathrm{R}=$ first ratoon from plant into fallow, $1 \mathrm{RR}$ = first ratoon from replant crop, and so on.

${ }^{\mathrm{c}}$ Triplicate quantitative polymerase chain reaction (qPCR) conducted on concentrated aqueous suspension from pooled leaf sheath biopsies (LSB) collected from the first green leaf sheath of 50 stalks, using modified primer Lxx202B and Lxx331 from Grisham et al. (2007). Two of three positive reactions with melt curves matching those obtained from pure cultures of Leifsonia xyli subsp. xyli were considered positive samples.

${ }^{\mathrm{d}}$ Mean cycle threshold $(\mathrm{Ct})$ value for all positive $\mathrm{qPCR}$ reactions.

e Conventional PCR on LSB samples using L. xyli subsp. xyli-specific Cxx1 and Cxx2 primers (Pan et al. 1998), coupled with agarose gel electrophoresis.

${ }^{\mathrm{f}}$ Conventional PCR (Pan et al. 1998) on duplicate aliquots of expressed xylem sap samples taken for evaporative-binding enzyme immunoassay (EB-EIA)/phase contrast microscopy (PCM) analysis.

g Field result for combination of EB-EIA and PCM on expressed xylem sap samples.

${ }^{\mathrm{h}}$ Sequence identification: $L x x=L . x y l i$ subsp. $x y l i$ and non $L x x=$ strains putatively belonging to the genus Leifsonia but distinct from $L . x y l i$ subsp. $x y l i$.

${ }^{\mathrm{i}}$ Symbols: $\mathrm{n} / \mathrm{a}=$ not applicable and $*$ indicates that the sequence for this sample could not be obtained owing to consistently weak amplicon produced with Leifsonia-generic primers. 
PCR. RSD was diagnosed in samples from all months, with the exception of April (two samples submitted) and August (no samples submitted). Repeated testing of known infected fields 160 and 168 showed that RSD could be detected between January and April, with sugarcane ranging from 3 to 14 months postemergence (Table 2). Field 161, called positive via EB-EIA/PCM, was never determined to be infected using any combination of PCR techniques throughout the course of this study.

Melt-curve characteristics and plant amplification control. A specific melt-curve peak at $87.3 \pm 0.5^{\circ} \mathrm{C}$ was detected for $L$. xyli subsp. xyli from the dilution series of pure culture. An identical melt-curve peak was detected by LSB-qPCR for two or more technical replicates in 27 diagnostic comparison fields. These results confirmed the LSB-PCR and sequencing results for 18 of these fields (Table 1), and are consistent with the higher sensitivity of qPCR over conventional PCR, determined using a dilution series of bacterial culture (see sensitivity, below). With the exception of one LSB template, all also amplified using the host-specific qPCR-inhibition control primers, producing a melt-curve peak at $80 \pm 0.5^{\circ} \mathrm{C}$. A new template was prepared from this LSB sample and LSB-qPCR was repeated with successful amplification of the plant control locus, while $L$. xyli subsp. xyli primers confirmed the negative test result for this field.

Expressed xylem sap diagnostic comparison. PCR on xylem sap samples detected $L$. xyli subsp. xyli in a total of 12 fields. From the 48 tubes of xylem sap from these fields, the 26 that were PCR positive included 12 that were EB-EIA negative, 8 that returned an initial EBEIA positive result but were deemed negative via PCM, and 6 that were EB-EIA and PCM positive (Table 3). The 19 tubes that recorded an initial EB-EIA absorbance of $>0.05$ were subjected to retesting. For all but one tube, the retest absorbance was lower than the initial absorbance (Table 3).

PCR and qPCR sensitivity. Conventional PCR on a dilution series of cultured $L$. xyli subsp. xyli was able to detect up to the fourth dilution, which represented approximately 10,000 CFU ml ${ }^{-1}$ (Table 4). The same sensitivity was found for the published qPCR primers of Grisham et al. (2007). With the modified forward primer Lxx202B, L. xyli subsp. xyli was detected to the fifth dilution, or approximately $1,000 \mathrm{CFU} \mathrm{ml} \mathrm{in}^{-1}$ inCR, with consistently lower cycle threshold values than the original primer.

\section{Discussion}

Effective detection of the RSD causal agent $L$. xyli subsp. xyli is currently limited by the cost and time involved in sampling for xylem-sap-based methods and DNA extraction for PCR-based methods. In this study, we have shown that PCR directly on expressed xylem sap is more effective than EB-EIA/PCM, and that qPCR and conventional PCR on templates derived from pooled LSB detects RSD in more fields than either expressed xylem sap platform. The high proportion of false negatives using the long-standing standard EB-EIA/PCM diagnostic suggests that the incidence and impact of RSD is likely to have been significantly underestimated in Australia.
In total, 33 detections were recorded for the 100 fields of previously unknown RSD status (Table 1). Of these, LSB-qPCR detected L. $x y l i$ subsp. $x y l i$ in 27 fields, at the same time confirming the infection status of the $18 \mathrm{LSB}$ samples that were diagnosed positive using conventional PCR. Twelve fields were diagnosed positive by conventional PCR on xylem sap, including three fields which were negative based on the LSB methods. This may be due to random

Table 3. Diagnostic results of individual samples of expressed xylem sap that were positive for any one or combination of conventional polymerase chain reaction (PCR), evaporative-binding enzyme immunoassay (EB-EIA), and phase contrast microscopy $(\mathrm{PCM})^{\mathrm{a}}$

\begin{tabular}{|c|c|c|c|c|c|}
\hline Field code & Xylem sample & PCR & EB-EIA & EB-EIA (B) & PCM \\
\hline 018 & 1 & + & 0.14 & 0.08 & + \\
\hline 018 & 2 & + & 0.32 & 0.13 & + \\
\hline 018 & 3 & + & 0.35 & 0.15 & + \\
\hline 018 & 4 & + & 0.40 & 0.09 & + \\
\hline 022 & 3 & + & 0.06 & 0.23 & + \\
\hline 004 & 1 & + & 0.28 & 0.21 & + \\
\hline 161 & 4 & - & 0.27 & 0.26 & + \\
\hline 010 & 4 & - & 0.11 & 0.09 & + \\
\hline 158 & 1 & - & 0.34 & 0.13 & + \\
\hline 030 & 2 & - & 0.16 & 0.02 & - \\
\hline 020 & 4 & - & 0.24 & 0.00 & - \\
\hline 035 & 1 & + & 0.10 & 0.02 & - \\
\hline 035 & 2 & + & 0.12 & 0.09 & - \\
\hline 015 & 1 & + & 0.18 & 0.05 & - \\
\hline 015 & 1 & + & 0.22 & 0.07 & - \\
\hline 160 & 3 & + & 0.33 & 0.01 & - \\
\hline 168 & 4 & + & 1.32 & 0.01 & - \\
\hline 017 & 3 & + & 0.16 & 0.09 & - \\
\hline 013 & 2 & + & 0.25 & 0.03 & - \\
\hline 004 & 3 & + & 0.02 & $\ldots$ & $\ldots$ \\
\hline 004 & 4 & + & 0.01 & $\ldots$ & $\ldots$ \\
\hline 204 & 1 & + & 0.00 & $\ldots$ & $\ldots$ \\
\hline 204 & 2 & + & 0.00 & $\ldots$ & $\ldots$ \\
\hline 204 & 4 & + & 0.00 & $\ldots$ & $\ldots$ \\
\hline 039 & 1 & + & 0.00 & $\ldots$ & $\ldots$ \\
\hline 039 & 2 & + & 0.01 & $\ldots$ & $\ldots$ \\
\hline 015 & 2 & + & 0.00 & $\ldots$ & $\ldots$ \\
\hline 160 & 4 & + & 0.01 & $\ldots$ & $\ldots$ \\
\hline 013 & 3 & + & 0.00 & $\ldots$ & $\ldots$ \\
\hline 017 & 2 & + & 0.00 & $\ldots$ & $\ldots$ \\
\hline 030 & 3 & + & 0.00 & $\ldots$ & $\ldots$ \\
\hline
\end{tabular}

${ }^{\text {a }}$ Field codes correspond to those in Table 1. Four tubes ( 1 to 4$)$ were tested from each field, with each tube containing a pooled xylem sample from four stalks. Any sample with an EB-EIA absorbance of $>0.05$ was subjected to retesting (EB-EIA [B]), with confirmation of infection only after PCM. Samples with an initial EB-EIA absorbance $<0.05$ were not subject to retesting or PCM examination.

Table 2. Time series of leaf sheath biopsy (LSB) polymerase chain reaction (PCR) testing of fields ${ }^{\mathrm{a}}$

\begin{tabular}{|c|c|c|c|c|c|}
\hline Field code & Variety & Crop class & Date sampled & Age (months) & LSB-PCR \\
\hline 160 & BN83-3120 & $1 \mathrm{R}$ & 25 August 2014 & 11 & + \\
\hline 160 & BN83-3120 & $2 \mathrm{R}$ & 17 February 2015 & 3 & + \\
\hline 160 & BN83-3120 & $2 \mathrm{R}$ & 20 March 2015 & 4 & + \\
\hline 160 & BN83-3120 & $2 \mathrm{R}$ & 23 April 2015 & 5 & + \\
\hline 160 & BN83-3120 & $2 \mathrm{R}$ & 2 January 2016 & 14 & + \\
\hline 168 & Q232 & $1 \mathrm{R}$ & 25 August 2014 & 11 & + \\
\hline 168 & Q232 & $2 \mathrm{R}$ & 17 February 2015 & 3 & + \\
\hline 168 & Q232 & $2 \mathrm{R}$ & 20 March 2015 & 4 & + \\
\hline 168 & Q232 & $2 \mathrm{R}$ & 23 April 2015 & 5 & + \\
\hline 161 & Q208 & $\mathrm{P}$ & 25 August 2014 & 11 & - \\
\hline 161 & Q208 & $\mathrm{P}$ & 17 February 2015 & 17 & - \\
\hline 161 & Q208 & $\mathrm{P}$ & 20 March 2015 & 18 & - \\
\hline 161 & Q208 & $\mathrm{P}$ & 23 April 2015 & 19 & - \\
\hline
\end{tabular}

${ }^{a}$ Age signifies months after planting (field 161) or harvesting (fields 160 and 168). LSB-PCR result was for conventional PCR employed throughout the time series. Additionally, all fields were tested using LSB-qPCR for the first screening, with the results matching those of LSB-PCR. 
sampling effects or higher titers of $L$. xyli subsp. xyli in basal nodes from which xylem sap is expressed (Bailey 1977; Harrison and Davis 1988). All PCR detections were confirmed as L. xyli subsp. xyli through diagnostic melt curves in $\mathrm{qPCR}$ or DNA sequence analysis of conventional PCR products. EB-EIA/PCM gave positive results for six fields; however, only three of these were PCR and sequence confirmed, while three were determined to be false positives based on the presence of closely related Leifsonia spp. in the samples. These novel strains, detected through generic Leifsonia primers (Young 2003), apparently triggered a positive response to the polyclonal antibodies used in EB-EIA and, presumably, had morphologies sufficiently similar to $L$. xyli subsp. xyli to make the false microscopic confirmation. They are distinct from all described Leifsonia spp., including the L. xyli subsp. cynodontis-like strains associated with Australian grasses (Mills et al. 2001), and their epidemiological significance is currently under examination. Discounting these three EB-EIA/PCM false positives, and notwithstanding the possibility of undetected infections in other fields (because 30 fields were confirmed positive for $L$. xyli subsp. xyli), the diagnostic efficiency of the techniques were as follows: LSB-qPCR (90\%), LSBPCR (60\%), conventional PCR on expressed xylem sap (40\%), and EB-EIA/PCM (10\%).

Although diagnostic accuracy may be affected by seasonal fluctuations in the titer of L. xyli subsp. xyli (Croft et al. 1994; Harrison and Davis 1988; Roach 1990), our research shows that the bacterium could be detected throughout the year using the LSB methodology. For the additional 139 Queensland samples, RSD was diagnosed using LSB-qPCR and LSB-PCR in all areas from which samples were received and in all months where more than two samples were received. Monthly sampling of two known infected fields further demonstrated that $L$. xyli subsp. xyli could be detected during all months sampled, and infections were detected in sugarcane ranging from 3 to 14 months old (Table 2). This is important in that it extends the effective sampling period for RSD. Because LSB sampling removes the requirement for stalks, it can be deployed on crops at a much younger age, facilitating more extensive sampling and timely diagnoses.

A wide range of sensitivities have been reported for diagnostic assays for $L$. xyli subsp. xyli. From pure cultures, the present study could detect as few as 10 cells $\mu l^{-1}$ through conventional PCR and qPCR using the published primers of Grisham et al. (2007), while qPCR using the corrected primers reached the theoretical detection limit of 1 cell $\mu 1^{-1}$ (Table 4). Because the bacterial titers in the dilution series were determined by plate counts, there is the possibility that a proportion of nonviable cells in the suspensions acted as PCR templates but did not result in plate colonies, while growth from closely adjacent cells on the plates may appear as single colonies. Although these possibilities would tend to inflate the sensitivity of the assays, the sensitivities reported here correspond favorably with other research.
Using conventional PCR targeting the IGS between the $16 \mathrm{~S}$ and 23S rRNA genes, Fegan et al. (1998) reported detection of 22 L. xyli subsp. xyli cells per reaction, while Pan et al. (1998) could detect 1 pg of $L$. xyli subsp. xyli genomic DNA. This can be calculated to be 356 cells/reaction, based on the single copy of the rRNA operon per bacterium, known genome size of 2,584,158 bp (Monteiro-Vitorello et al. 2004), and assuming an average molecular mass of 654.08 Da per base pair, given the $68 \% \mathrm{G}+\mathrm{C}$ content. Using probe-based qPCR, Pelosi et al. (2013) reported detection of 10 copies of bacterial genomic DNA per reaction, which is equivalent to the sensitivity reported here for conventional PCR, and less sensitive than qPCR using the corrected primers of Grisham et al. (2007). Using the uncorrected primers of Grisham et al. (2007), Farahani et al. (2015) claimed consistent detection of L. xyli subsp. xyli DNA in $0.2 \mathrm{fg}$ of total genomic DNA extracted from expressed fibrovascular fluid from two different sugarcane varieties. This result is questionable because it represents consistent amplification of 0.07 target molecules per reaction with mismatched primers that are 10-fold less sensitive than the qPCR primers tested in this study. Because the method of determining the DNA concentrations was not reported, it is possible that the starting concentration was several orders of magnitude higher than stated, that there were errors in establishing the dilution series, or that there was contamination in the qPCR protocols. For LAMP, Ghai et al. (2014) reported detection of 3 pg of $L$. xyli subsp. xyli DNA per reaction or, by calculation, approximately 1,000 cells/reaction. The sensitivity reported by Liu et al. (2013) was 10-fold lower, albeit based on whole DNA extracted from fibrovascular sap, which must also include nontarget DNA. Other studies did not report diagnostic test sensitivity (Gao et al. 2008; Grisham et al. 2007; Taylor et al. 2003). The EB-EIA platform reportedly has a detection threshold of $10^{6}$ cells ml$^{-1}$ (Croft et al. 1994), or a thousand times less sensitive than qPCR. Based on the current results and sensitivities reported elsewhere, qPCR is the most sensitive test available for $L$. xyli subsp. xyli.

In a direct comparison on duplicate expressed xylem sap, conventional PCR was more sensitive than EB-EIA/PCM. L. xyli subsp. xyli was detected in 26 samples using PCR, including $12(46 \%)$ that did not register an EB-EIA response. A high proportion of $21 \%$ false negatives for EB-EIA relative to other immunological methods has previously been reported (Hoy et al. 1999). There was a high disparity between the initial EB-EIA absorbance and the retest absorbances of expressed xylem sap (Table 3). Of the 19 tubes that initially registered an absorbance of greater than 0.05, only 1 tube had a retest value equal to or greater than the initial test, while the remaining samples had reduced absorbances. This suggests either degeneration of samples or technical processing issues. Eight of these tubes, comprising samples from six fields, were determined to be negative for $L$. xyli subsp. xyli using PCM but were positive using PCR, meaning that the imposition of PCM confirmation directly led to another six

Table 4. Summary of Leifsonia xyli subsp. xyli dilution series and plate culture experiment with expected number of CFU in $1 \mu l$ of template and mean cycle threshold $(\mathrm{Ct})$ value for all positive reactions

\begin{tabular}{|c|c|c|c|c|c|c|c|c|}
\hline $\begin{array}{l}\text { Dilution } \\
\text { series }\end{array}$ & $\begin{array}{l}\text { Dilution } \\
\text { factor }\end{array}$ & $\begin{array}{c}\text { Average } \\
\text { colony count }^{\mathrm{a}}\end{array}$ & $\begin{array}{l}\text { Projected } \\
\text { CFU } \mu l^{-1}\end{array}$ & $\begin{array}{c}\text { qPCR Lxx202B } \\
\text { Lxx331b }^{b}\end{array}$ & $\begin{array}{c}\text { Mean } \\
\text { Ct value }\end{array}$ & $\begin{array}{c}\text { qPCR Lxx202 } \\
\text { Lxx331 }^{\mathrm{d}}\end{array}$ & $\begin{array}{c}\text { Mean } \\
\text { Ct value }\end{array}$ & $\begin{array}{c}\text { PCR Cxx1 } \\
\text { Cxx2 } 2^{\mathrm{e}}\end{array}$ \\
\hline 1 & $1 \times 10^{\circ}$ & TMTC & $5,937.50$ & +++ & 18.28 & +++ & 24.93 & + \\
\hline 2 & $1 \times 10^{1}$ & TMTC & 712.50 & +++ & 21.07 & +++ & 27.91 & + \\
\hline 3 & $1 \times 10^{2}$ & TMTC & 85.50 & +++ & 24.22 & +++ & 31.09 & + \\
\hline 4 & $1 \times 10^{3}$ & $1,025.5$ & 10.26 & ++- & 28.11 & +++ & 33.91 & + \\
\hline 5 & $1 \times 10^{4}$ & 83.0 & 0.83 & +++ & 29.44 & --- & $\mathrm{n} / \mathrm{a}$ & - \\
\hline 6 & $1 \times 10^{5}$ & 12.5 & 0.13 & --- & $\mathrm{n} / \mathrm{a}$ & --- & $\mathrm{n} / \mathrm{a}$ & - \\
\hline 7 & $1 \times 10^{6}$ & 0.0 & 0.02 & --- & $\mathrm{n} / \mathrm{a}$ & --- & $\mathrm{n} / \mathrm{a}$ & - \\
\hline 8 & $1 \times 10^{7}$ & 0.0 & 0.00 & --- & $\mathrm{n} / \mathrm{a}$ & --- & $\mathrm{n} / \mathrm{a}$ & - \\
\hline 9 & $1 \times 10^{8}$ & 0.0 & 0.00 & --- & $\mathrm{n} / \mathrm{a}$ & --- & $\mathrm{n} / \mathrm{a}$ & - \\
\hline
\end{tabular}

a Average number of colonies counted on duplicate plates after $100 \mu \mathrm{l}$ of bacterial suspension from each dilution was plated on modified M-SC medium. TMTC $=$ too many to count.

${ }^{\mathrm{b}}$ Quantitative polymerase chain reaction (qPCR) using modified forward primer Lxx202 (Lxx202B) and Lxx331 from Grisham et al. (2007). All qPCR assays were conducted in triplicate, with the mean cycle threshold $(\mathrm{Ct})$ values shown for all positive reactions.

c Symbol: $\mathrm{n} / \mathrm{a}=$ not applicable.

d qPCR using published primers Lxx202 and Lxx331 from Grisham et al. (2007).

e Conventional PCR using Cxx1 and Cxx2 primers from Pan et al. (1998). 
false-negative field results using the standard diagnostic platform. This level of disparity between the results of the tests, retests, and microscopic confirmations casts doubt over the overall utility of EB-EIA/PCM for the diagnosis of RSD.

In addition to more than tripling the sample number, the improved detection rate of LSB platforms over the xylem sap platforms may be explained by the removal of sampling biases. From the 30 fields that were confirmed infected through any combination of the PCR techniques, only 26 of 120 (22\%) xylem sap samples from 12 fields were positive for $L$. xyli subsp. xyli (Table 3 ). In just one case were all four tubes from a field positive. Thus, using the recommended sampling strategy (Croft and Cox 2013), the majority of expressed xylem sap samples taken from infected fields are unlikely to contain $L$. xyli subsp. xyli. There are a number of possible reasons for this. As its names implies, RSD stunts the plant but, for effective xylem sap expression, the largest stalks in poorly grown stools are selected (Croft and Cox 2013). Furthermore, it is easier to extract xylem sap from noninfected versus infected xylem vessels because they are not occluded (Teakle et al. 1978). Therefore, in a mixed sample, it is likely that a relatively higher proportion of pooled xylem sap will come from uninfected stalks and fibrovascular vessels, potentially diluting the target organism below the detection threshold. In contrast, LSB samples can be taken from smaller, more stunted plants, which may be more likely to be infected. For these reasons, in addition to the time and labor involved, collecting xylem sap is an inefficient sampling method for RSD.

A potential criticism of this work is that the comparisons were not identical for all four methods because, although the same 100 fields were tested, the sampling regimes necessarily differed. However, using identical expressed xylem sap samples, it was demonstrated that PCR was both more sensitive and specific than EB-EIA/PCM, while qPCR and conventional PCR screening of 50 LSB samples were more likely to diagnose RSD in a field than xylem sap samples from 16 stalks. If the question is whether or not a stalk of sugarcane is infected with $L$. xyli subsp. $x y l i$, then PCR is clearly a more sensitive test than EB-EIA or PCM. However, if a grower wants to know if a field from which to propagate new crops is free from infection, then qPCR and conventional PCR on LSB samples offers a significant improvement over expressed xylem sap methods.

In addition to enhanced diagnostic efficiency, LSB-based RSD diagnostics have several advantages over existing platforms. Sample collection is rapid, efficient, and independent of climatic conditions, such as dry or hot weather, that may restrict the amount of xylem sap that may be expressed. The technique is readily adopted, with over 700 fields screened throughout Australia since 2013. No DNA extraction steps are required, which otherwise would increase time and processing costs. There is the potential that this sampling system could also be applied to other sugarcane diseases such as leaf scald, smut, and chlorotic streak. Likewise, it may also be effective in screening for diseases in other crops such as sorghum and maize. Potential end users may select the more sensitive and expensive qPCR technique to achieve the highest accuracy but, with lower consumable costs and only basic laboratory requirements, conventional PCR on LSB samples holds significant promise for reducing the impact of RSD, particularly in developing nations where infrastructure may be limited but sugar production is a key driver of economic activity.

\section{Acknowledgments}

This work was supported by Sugar Research Australia (SRA) grant 2014/086. We thank F. Driver (SRA) for project support, N. Thompson (SRA) for providing plant control primer sequences, A. Johnson (SRA) for conducting the EB-EIA and PCM analyses, S. Hollis (Sunshine Sugar) for assistance with field work, and J. Harris and her team for logistical assistance and reviewing the manuscript.

\section{Literature Cited}

Bailey, R. A. 1977. The systemic distribution and relative occurrence of bacteria in sugarcane varieties affected by ratoon stunting disease. Proc. S. Afr. Sugar Technol. Assoc. 51:55-56.

Brumbley, S. M., Petrasovits, L. A., Birch, R. G., and Taylor, P. W. J. 2002. Transformation and transposon mutagenesis of Leifsonia xyli subsp. xyli, causal organism of ratoon stunting disease of sugarcane. Mol. Plant-Microbe Interact. 15:262-268.

Brumbley, S. M., Petrasovits, L. A., Hermann, S. R., Young, A. J., and Croft, B. J. 2006. Recent advances in the molecular biology of Leifsonia xyli subsp. xyli, causal organism for ratoon stunting disease of sugarcane. Australas. Plant Pathol. 35:681-689.

Carvalho, G., da Silva, T. G. E. R., Munhoz, A. T., Monteiro-Vitorello, C. B., Azevedo, R. A., Melotto, M., and Camargo, L. E. A. 2016. Development of a qPCR for Leifsonia xyli subsp. xyli and quantification of the effects of heat treatment of sugarcane cuttings on Lxx. Crop Prot. 80:51-55.

Croft, B. J., and Cox, M. C. 2013. Procedures for the establishment and operation of approved-seed plots, 4th ed. Online publication. Sugar Research Australia. http://www.sugarresearch.com.au/icms_docs/170755_Procedures_for_the Establishment and Operation_of_Approved_Seed_Plots_MN07002.pdf

Croft, B. J., Green, J., Parsons, D., and Royal, A. 2004. BSES RSD laboratories 10 years of service. Proc. Aust. Soc. Sugar Cane Technol. 26:26-34.

Croft, B. J., Greet, A. D., Leaman, T. M., and Teakle, D. S. 1994. RSD diagnosis and varietal resistance screening in sugarcane using the EB-EIA technique. Proc. Aust. Soc. Sugar Cane Technol. 16:143-151.

Davis, M. J., Gillaspie, A. G., Jr., Harris, R. W., and Lowson, R. H. 1980. Ratoon stunting disease of sugarcane: Isolation of the causal bacterium. Science 210: 1365-1367.

Davis, M. J., Gillaspie, A. G., Jr., Vidaver, A. K., and Harris, R. W. 1984. Clavibacter: A new genus containing some phytopathogenic coryneform bacteria, including Clavibacter xyli subsp. xyli sp. nov., subsp. nov. and Clavibacter xyli subsp. cynodontis subsp. nov., pathogens that cause ratoon stunting disease of sugarcane and bermudagrass stunting disease. Int. J. Syst. Bacteriol. 34: 107-117.

Evtushenko, L. I., Dorofeeva, L. V., Subbotin, S. A., Cole, J. R., and Tiedje, J. M 2000. Leifsonia poae gen. nov., sp. nov., isolated from nematode galls on Poa annua, and reclassification of 'Corynebacterium aquaticum' Leifson 1962 as Leifsonia aquatica (ex Leifson 1962) gen. nov., nom. rev., comb. nov. and Clavibacter xyli Davis et al. 1984. with two subspecies as Leifsonia xyli (Davis et al. 1984) gen. nov., comb. nov. Int. J. Syst. Evol. Microbiol. 50: 371-380.

Farahani, A. S., Taghavi, S. M., and Taher-Khani, K. 2015. Comparison of conventional, nested and real-time PCR for detection of the causal agent of ratoon stunt in Iran. J. Plant Pathol. 97:259-263.

Fegan, M., Croft, B. J., Teakle, D. S., Hayward, A. C., and Smith, G. R. 1998 Sensitive and specific detection of Clavibacter xyli subsp. xyli, causal agent of ratoon stunting disease, with a polymerase chain reaction-based assay. Plant Pathol. 47:495-504.

Gao, S. J., Pan, Y. B., Chen, R. K., Chen, P. H., Zhang, H., and Xu, L. P. 2008 Quick detection of Leifsonia xyli subsp. xyli by PCR and nucleotide sequence analysis of PCR amplicons from Chinese Leifsonia xyli subsp. xyli isolates. Sugar Tech 10:334-340.

Ghai, M., Singh, V., Martin, L. A., McFarlane, S. A., van Antwerpen, T., and Rutherford, R. S. 2014. A rapid and visual loop-mediated isothermal amplification assay to detect Leifsonia xyli subsp. xyli targeting a transposase gene. Lett. Appl. Microbiol. 59:648-657.

Gillaspie, A. G., Jr. 1987. Method for detecting Clavibacter xyli subsp. xyli from sugarcane leaves. Plant Dis. 71:691-693.

Gillaspie, A. G., Jr., and Teakle, D. S. 1989. Ratoon stunting disease. Pages 59-80 in: Sugarcane Diseases of the World, Vol. I (revised). Elsevier, Amsterdam.

Grisham, M. P., Pan, Y. B., and Richard, E. P., Jr. 2007. Early detection of Leifsonia xyli subsp. xyli in sugarcane leaves by real-time polymerase chain reaction. Plant Dis. 91:430-434.

Harrison, A. A., and Davis, M. J. 1988. Colonization of vascular tissues by Clavibacter xyli subsp. xyli in stalks of sugarcane cultivars differing in susceptibility to ratoon stunting disease. Phytopathology 78:722-727.

Hoy, J. W., Grisham, M. P., and Damann, K. E., Jr. 1999. Spread and increase of ratoon stunting disease of sugarcane and comparison of disease detection methods. Plant Dis. 83:1170-1175.

Hughes, C. G., and Steindl, D. R. L. 1956. Some further developments in the study of ratoon stunting disease in Queensland. Proc. Int. Soc. Sugar Cane Technol. 9: $1012-1022$

Liu, J., Xu, L., Guo, J., Chen, R., Grisham, M. P., and Que, Y. 2013. Development of loop-mediated isothermal amplification for detection of Leifsonia xyli subsp $x y l i$ in sugarcane. BioMed Res. Int. 2013:Article ID 357692. doi:10.1155/2013/ 357692

Mills, L., Leaman, T. M., Taghavi, S. M., Shackel, L., Dominiak, B. C., Taylor, P. W. J., Fegan, M., and Teakle, D. S. 2001. Leifsonia-like bacteria are endophytes of grasses in eastern Australia. Australas. Plant Pathol. 30:145-151.

Monteiro-Vitorello, C. B., Camargo, L. E. A., Van Sluys, M. A., Kitajima, J. P., Truffi, D., do Amaral, A. M., Harakava, R., de Oliveira, J. C. F., Wood, D., de Oliveira, M. C., Miyaki, C., Takita, M. A., da Silva, A. C. R., Furlan, L. R., Carraro, D. M., Camarotte, G., Almeida, N. F., Jr., Carrer, H., Coutinho, L. L., El-Dorry, H. A., Ferro, M. I. T., Gagliardi, P. R., Giglioti, E., Goldman, M. H. S., Goldman, G. H., Kimura, E. T., Ferro, E. S., Kuramae E. E., Lemos, E. G. M., Lemos, M. V. F., Mauro, S. M. Z., Machado, M. A., Marino, C. L., Menck, C. F., Nunes, L. R., Oliveira, R. C., Pereira, G. G., Siqueira, W., de Souza, A. A., Tsai, S. M., Zanca, A. S., Simpson, A. J. G., Brumbley, S. M., and Setubal, J. C. 2004. The genome sequence of the 
Gram-positive sugarcane pathogen Leifsonia xyli subsp. xyli. Mol. PlantMicrobe Interact. 17:827-836.

Pan, Y.-B., Grisham, M. P., Burner, D. M., Damann, K. E., Jr., and Wei, Q. 1998. A polymerase chain reaction protocol for the detection of Clavibacter xyli subsp. $x y l i$, the causal bacterium of sugarcane ratoon stunting disease. Plant Dis. 82:285-290.

Pelosi, C. S., Lourenço, M. V., Silva, M., Santos, A. Z., França, S. C., and Marins, M. 2013. Development of a Taqman real-time PCR assay for detection of Leifsonia xyli subsp. xyli. Trop. Plant Pathol. 38:343-345.

Roach, B. T. 1990. Sampling and diagnostic procedures for testing sugarcane resistance to ratoon stunting disease by phase contrast microscopy. Proc. Aust. Soc. Sugar Cane Technol. 12:111-119.

Tamura, K., Stecher, G., Peterson, D., Filipski, A., and Kumar, S. 2013. MEGA6: Molecular Evolutionary Genetics Analysis Version 6.0. Mol. Biol. Evol. 30: 2725-2729.

Taylor, P. W. J., Petrasovits, L. A., Van der Velde, R., Birch, R. G., Croft, B. J., Fegan, M., Smith, G. R., and Brumbley, S. M. 2003. Development of PCRbased markers for detection of Leifsonia xyli subsp. xyli in fibrovascular fluid of infected sugarcane plants. Australas. Plant Pathol. 32:367-375.

Teakle, D. S., Appleton, J. M., and Steindl, D. R. L. 1978. Anatomical basis for resistance of sugarcane to ratoon stunting disease. Physiol. Plant Pathol. 12:83-91.
Teakle, D. S., Smith, P. M., and Steindl, D. R. L. 1973. Association of a small coryneform bacterium with the ratoon stunting disease of sugarcane. Aust. J. Agric. Res. 24:869-874

Young, A. J. 2003. Genetic diversity of Leifsonia xyli subsp. xyli, causal agent of ratoon stunting disease of sugarcane. Ph.D. thesis, Macquarie University, North Ryde, NSW, Australia.

Young, A. J., and Brumbley, S. M. 2004 Ratoon stunting disease of sugarcane: History, management and current research. Pages 97-124 in: Sugarcane Pathology, Vol. 3: Bacterial and Nematode Diseases. G. P. Rao, A. Salem Saumtally, and P. Rott, eds. Science Publishers Inc., Enfield, NH.

Young, A. J., Lokes, S., Davis, W., and Aitken, R. 2012. Reassessing RSD Insights from Harwood. Online publication. Proc. Aust. Soc. Sugar Cane Technol. Vol. 34. https://www.researchgate.net/publication/281287411_ Reassessing rsd Insights from harwood

Young, A. J., Nock, C. J., Martin, A., and Ensbey, M. 2014. Novel diagnostic for ratoon stunting disease: Development and implications for RSD management. Proc. Aust. Soc. Sugar Cane Technol. 36:237-243.

Young, A. J., Petrasovits, L. A., Croft, B. J., Gillings, M., and Brumbley, S. M 2006. Genetic uniformity of international isolates of Leifsonia xyli subsp. $x y l i$, causal agent of ratoon stunting disease of sugarcane (Saccharum interspecific hybrids). Australas. Plant Pathol. 35:503-511. 